\title{
THE RIGHT OF ACCESS TO ENVIRONMENTAL INFORMATION IN THE LIGHT OF THE CASE C-673/13 P OF 23 NOVEMBER 2016 - EUROPEAN COMMISSION V STICHTING GREENPEACE NEDERLAND
}

\author{
JUSTYNA BAZYLIŃSKA-NAGLER*
}

\section{INTRODUCTION}

The 'most ambitious venture in the area of 'environmental democracy' so far undertaken under the auspices of the United Nations' - in these words, Kofi Annan, then Secretary-General of the United Nations ${ }^{1}$, described the Aarhus Convention $^{2}$. This new kind of environmental agreement, linking human rights with environmental rights, acknowledges our obligation to future generations and establishes that only the involvement of all stakeholders leads to the accomplishment of sustainable development. ${ }^{3}$ Promotion of more effective public participation in the decision-making proces has been increasing steadily on the part of the competent bodies, as well as the accountability of decision-making and contributing to public understanding and support for the decisions made in environmental matters. In order to be able to ensure that the competent authorities take the right decisions and to participate effectively in decision-making, the public must know that the emissions were correctly or incorrectly assessed and must be thoroughly informed so as to understand how those emissions could affect the environment. ${ }^{4}$

\footnotetext{
DOI: 10.1515/wrlae-2018-0018

* Phd in Law, Assistant Professor, Department of International and European Law, Wroclaw University; justyna.bazylinska-nagler@uwr.edu.pl

${ }^{1}$ Peter Oliver, 'Access to Information and to Justice in EU Environmental Law: The Aarhus Convention’ (2013) 36 Fordham International Law Journal 1424.

${ }^{2}$ Convention on Access to Information, Public Participation in Decision-making and Access to Justice in Environmental Matters, Aarhus, Denmark [1998] United Nations Treaty Series vol 2161, 447 (Aarhus Convention).

${ }^{3}$ United Nations Economic Commission for Europe, Convention on Access to Information, Public Participation in Decision-making and Access to Justice in Environmental Matters (Aarhus Convention) The Aarhus Convention: An implementation guide (United Nations Publications 2014).

${ }^{4}$ Regulation (EC) No 1367/2006 of the European Parliament and of the Council of 6 September 2006 on the application of the provisions of the Aarhus Convention on Access to Information, Public Participation in Decision-making and Access to Justice in Environmental
} 
The main thesis of this article is that there is a significant contradiction between environmental democracy standards in EU law and the protection of confidential commercial or industrial information. On the one side, we vote for greater openness, accountability and legitimacy of public administration, especially in environmental law. On the other side, businesses struggle to assert the privilege to withhold information that would identify their effects on the environment. Undoubtly, access to data, including chemical identity, volume and locations of discharges, and data on health and ecological effects is crucial to environmental health and safety management. ${ }^{5}$ There are numerous EU legal obligations for Member States to collect data on the environment and corresponding obligations for companies to provide data. Therefore, the quantity and quality of relevant information compiled by authorities is increasing steadily. Thus, the problem of the protection of confidential commercial or industrial information in environmental law emerges increasingly.

Bearing all that in mind, a significant part of this article has become a commentary on a very recent Court of Justice of the European Union judgment in appeal of 23rd November 2016 - European Commission v Greenpeace Nederland and Pesticide Action Network Europe. ${ }^{6}$ Stichting Greenpeace Nederland (Greenpeace) and Pesticide Action Network Europe (PAN Europe) have been attempting for some time to gain access to the records concerning the authorisation of glyphosate for use in plant protection products. Glyphosate is one of the most widely used active substances for plant protection. Traces of it can thus be found in the food chain, and ultimately in German beer; there is dispute as to whether it is carcinogenic. In line with the EU's access to documents laws, information that would harm the commercial interests of a third party can not be made public if there is not an overriding public interest justifying such a disclosure. The Commission disclosed some of the documents in question, but withheld others on the grounds of protection of the commercial interests of the undertakings concerned. The General Court, on the other hand, ruled that the withheld documents also related to emissions into the environment and an overriding interest in their disclosure must have been presumed to exist. Finally, the Court of Justice deciding the case on appeal, confirmed a broad interpretation of the concept of 'information which relates to emissions into the environment' in the context of pesticides. ${ }^{7}$

\footnotetext{
Matters to Community institutions and bodies [2006] OJ L264/13, Recital 2 (Aarhus Regulation).

${ }^{5}$ Mary L Lyndon, 'Trade Secrets and Information Access in Environmental Law' in Rochelle C Dreyfuss \& Katherine J Strandburg (eds) The Law and Theory of trade secrecy: a handbook of contemporary research (Edward Elgar 2011).

${ }^{6}$ Case C-673/13 P Commission v Stichting Greenpeace Nederland and PAN Europe.

7 Opinion of advocate general Kokott delivered on 7 April 2016 (1) Case C 673/13 P European Commission v Stichting Greenpeace Nederland and Pesticide Action Network Europe (PAN Europe), para: 1-3.
} 


\section{THE Right TO BE INFORMED IN EUROPEAN ENVIRONMENTAL LAW}

\section{Genesis}

The road to Aarhus began with global policy statements and declarations and led through various international and regional instruments. To begin with, UN Resolution 2997 (XXV1l) of December 1972: 'Recognizing further that environmental problems of broad international significance fall within the competence of the United Nations system (...). Emphasizing that problems of the environment constitute a new and important area for international cooperation and that the complexity and interdependence of such problems require new approaches (...) intergovernmental and those non-governmental organizations that have an interest in the field of the environment should lend their full support and collaboration to the United Nations with a view to achieving the largest possible degree of co-operation and co-ordination' ${ }^{8}$ The Rio Declaration on Environment and Development $1992^{9}$ with its Principle 10 was of especially great importance for the developments that resulted in the Aarhus convention: 'Environmental issues are best handled with participation of all concerned citizens, at the relevant level. At the national level, each individual shall have appropriate access to information concerning the environment that is held by public authorities, including information on hazardous materials and activities in their communities, and the opportunity to participate in decisionmaking processes. States shall facilitate and encourage public awareness and participation by making information widely available. Effective access to judicial and administrative proceedings, including redress and remedy, shall be provided.' This direction was followed by the declaration 'The future we want', 2012; in para 43 one could read: 'We underscore that broad public participation and access to information and judicial and administrative proceedings are essential to the promotion of sustainable development...' 10

Nowadays, in Europe, the right of access to environmental information is rooted in: the Aarhus Convention, the European Court of Human Rights (ECHR) jurisprudence and EU law.

As seen in the preamble, the Aarhus Convention forges links between the development of one set of human rights, in particular those relating to the basic conditions of life, including the environment, and another set of human rights, those relating to human self-fulfilment, expression and action - 'By harnessing the energy of public participation, states can do more to stop environmental degradation and can work towards sustainability.' Article 1

\footnotetext{
${ }^{8}$ Resolution adopted by the General Assembly 2997 (XXVII). Institutional and financial arrangements for international environmental cooperation, A/RES/27/2997 <http://www.undocuments.net/a27r2997.htm>.

${ }^{9}$ Report of the United Nations conference on environment and development, Rio de Janeiro, 3-14 June 1992, $\quad$ A/CONF.151/26 (Vol <http://www.un.org/documents/ga/conf151/aconf15126-1annex1.htm>.

10 Declaration of the UN Conference on Sustainable Development, Rio (2012) <http://www.un.org/disabilities/documents/rio20_outcome_document_complete.pdf>.
} 
clearly states that the Aarhus Convention is about basic human rights - the rights of every person - 'In order to contribute to the protection of the right of every person of present and future generations to live in an environment adequate to his or her health and well-being, each Party shall guarantee the rights of access to information, public participation in decision-making, and access to justice in environmental matters in accordance with the provisions of this Convention'. ${ }^{11}$ It is one of the most explicit provisions of a fundamental right to a healthy environment in public international law. ${ }^{12}$

The Convention regulates the issue of access to environmental information in two separate articles. Article 4 regulates so called 'passive' disclosure of information while Article 5 addresses 'active' disclosure of information. The terms 'active' and 'passive' relate to the requirements of the public authorities. Thus, active information requirements impose a duty on public authorities to act affirmatively, whereas passive information provisions may require the establishment of systems and procedures, but do not require public authorities to act until triggered by a communication from the public. The concept of access to information concerns a separate legal institution; it is about openess of administration and access to governmental documents outside any pending procedures. Such a right is never granted only to NGOs. In all democratic countries this is a right granted to every person. In the majority of countries where environmetal information is subject to disclosure it is legally guaranteed via legislations called Freedom of Information Acts, which are general-purpose laws that apply to many kinds of governmental information. It means that usually the right of access to information is not limited only to environmental information but covers all (except for statutory exceptions) information and documents possesed by public administration, and this right is granted to every person i.e. access to information is not connected with participation in any given proceedings, and does not require any interest, legal or factual, to be demonstrated. ${ }^{13}$

For form's sake, it is impossible not to mention European Court of Human Rights (ECHR) jurisprudence, the relevant European Convention on Human Rights ${ }^{14}$ provisions and the corresponding Charter of Fundamental Rights of the Union ${ }^{15}$ articles. However, in view of their general language, reliance on the Convention and the Charter can usually be expected to lead to less

\footnotetext{
${ }^{11}$ United Nations Economic Commission for Europe, Convention on Access to Information, Public Participation in Decision-making and Access to Justice in Environmental Matters (Aarhus Convention) The Aarhus Convention: An implementation guide (United Nations Publications 2014), p. 43.

12 Adriana Fabra Aguilar and Neil Popovic, 'Lawmaking in the United Nations: the UN Study on Human Rights and the Environment' (1997) 17 Review of European Community \& International Environmental Law 197, 199 - at that time approx 60 countries and several federal states of the US had constitutional provisions concerning the right to a healthy environment, similarly the African Charter on Human and Peoples' Rights, adopted at Algiers on 27 June 1981, and the Additional Protocol to the American Convention on Human Rights, adopted in San Salvador on 17 November 1988.

${ }^{13}$ Jerzy Jendrośka, 'Public Information and Participation in EC Environmental Law; Origins, Milestones and Trends' in Richard Macrory (ed) Reflections on 30 years of EU environmental law. A High Level of Protection? (Europa Law Publishing 2006) 72-73.

14 Convention for the Protection of Human Rights and Fundamental Freedoms (1950), European Treaty Series 5 (Convention).

${ }^{15}$ [2012] OJ C326/02 (Charter).
} 
satisfactory results than the Aarhus Convention and the EU legislation ${ }^{16}$ considered below in the present article. In extreme cases, the ECHR has found that a failure by a state to inform the public about the danger posed by a factory or plant was a breach of Article 8 of the Convention, which relates to the right to privacy, family life and the home ${ }^{17}$. Article 7 of the Charter ${ }^{18}$ corresponds to Article 8 of the Convention and is therefore to be given the same meaning and scope. Article 10 of the European Convention on Human Rights, corresponding with Article 11 of the Charter, tends to be increasingly construed by the ECHR as a broad guarantee of freedom to receive information, bordering on the recognition of a right of access to information. As far as the specific question of access to court documents is concerned, the ECHR stated in Társaság a Szabadságjogokért v. Hungary ${ }^{19}$ that Hungary violated Article 10 of the Convention by refusing access to a nongovernmental organisation (NGO) to a complaint pending before the Constitutional Court concerning the constitutionality of amendments to the national Criminal Code. The ECHR held that it was an unnecessary interference with the freedom to receive information. It is perhaps worth highlighting that the ECtHR reached that conclusion in relation to a pending case before the Constitutional Court, in which access to the pleadings (the original application for review) was requested prior to the decision of the Constitutional Court. ${ }^{20}$

To conclude, the co-existence of general law on access to public information and law on access to environmental information creates two legal regimes in Europe. ${ }^{21}$ As a consequence, key legal problems of the relevant case law would base on a significant interplay and overlap between Aarhus Convention environmental information and Tromso Convention ${ }^{22}$ public information provisions application Article $15 \mathrm{TFEU}^{23}$ (before Art. 255

\footnotetext{
16 Nicholas De Sadeleer, 'Enforcing EUCHR Principles and Fundamental Rights in Environmental Cases' (2012) 39 Nordic Journal of International Law 39-74.

${ }^{17}$ Guerra v Italy, 116/1996/735/932, (1998, Eur. Ct. H.R.); see Tatar v Roumania, 67021/01 [2009].

${ }^{18}$ Explanations on Article 7, Explanations relating to the Charter of Fundamental Rights [2007] C 303/02

${ }^{19}$ Judgment of the ECtHR of 14 April 2009 in Társaság a Szabadságjogokért v Hungary (ECLI:CE:ECHR:2009:0414JUD003737405).

${ }^{20}$ Opinion of Advocate General Bobek delivered on 21 December 2016 (1) Case C 213/15 P Commission v Patrick Breyer, paras 87 - 88.

${ }^{21}$ Frankie Schram, 'From a General Right of Access to Environmental Information in the Aarhus Convention to a general right of Access to All Information in Official Documents. The Council of Europe's Tromsø Convention' in Marc Pallemaerts (eds), The Aarhus Convention at Ten: Interactions and Tensions Between Conventional International Law and EU Environmental Law (Europa Law Publishing 2011) 69.

${ }^{22}$ Council of Europe Convention on Access to Official Documents, Tromsø (2009) Council of Europe Treaty Series 205.

${ }^{23}$ Treaty on the Functioning of the European Union [2012] OJ C 326/01 (TFEU).
} 
TEC $^{24}$ ) or Regulation on public information access ${ }^{25}$ versus specific provisions dealing with environmental information access i.e.: Aarhus Regulation or Directive $1990 / 313^{26}$ followed by Directive 2003/4. ${ }^{27}$ Therefore, the schematic context of the various rules on access became the bone of contention in the case C 673/13 P European Commission v Stiching Greenpeace (...) discussed below.

\section{Environmental information access in EU law}

The Aarhus Convention has become a part of the EU Acquis. The European Union concluded the Convention by Council Decision in 2005. ${ }^{28}$ When doing so, it did not enter any reservations but, as specifically required by Article 19(5) of the Convention, it did make a detailed declaration as to the extent of its own powers with regard to matters governed by the Convention. ${ }^{29}$ Jerzy Jendrośka said that, there were a couple of milestones in the development of the European Union law concerning environmental rights of the public. The real breakthrough was the adoption of the Aarhus Convention in $1998 .^{30}$ The Union accounts for twenty-eight of the forty-six contracting parties to the Convention. Moreover, all the Member States are also parties to the Convention ${ }^{31}$. Member States implement Aarhus via EU law and independently. It is also worthy of mention that European Commission and the Court of Justice of the EU play a dual role in the application of the convention - as enforcers and as subjects of obligations.

The Convention has been implemented in EU law through Aarhus Regulation adressed to EU institutions, an environmental information access directive, several directives dealing with public participation, no legal instrument but only CJEU jurisprudence on access to justice adressed to Member States.

\footnotetext{
24 Treaty establishing the European Community [2002] OJ C 325/33.

${ }^{25}$ Regulation (EC) No 1049/2001 of the European Parliament and of the Council of 30 May 2001 regarding public access to European Parliament, Council and Commission documents [2001] OJ L145/43 (Public Access Regulation).

${ }^{26}$ Council Directive 90/313/EEC of 7 June 1990 on the freedom of access to information on the environment (1990) OJ L 158/0056.

${ }^{27}$ Directive 2003/4/EC of the European Parliament and of the Council of 28 January 2003 on public access to environmental information and repealing Council Directive 90/313/EEC [2003] OJ L 041/0026 (environmental information access directive).

${ }^{28}$ Decision 2005/370/EC of 17 February 2005 on the conclusion on behalf of the European Community, of the Convention on access to information, public participation in decisionmaking and access to justice in environmental matters [2005] OJ L124/1.

${ }^{29}$ Council Approval of Convention, supra note 3, at Annex; Aarhus Convention, supra note 1, art. 19(5) 'In their instruments of ratification, acceptance, approval or accession, the regional economic integration organisations... shall declare the extent of their competence with respect to the matters governed by this Convention'; Peter Oliver, 'Access to Information and to Justice in EU Environmental Law: The Aarhus Convention' (2013) 36 Fordham International Law Journal 1425.

$30 \mathrm{~J}$ Jendrośka, 'Public Participation in Environmental Decision-Making Interactions Between the Convention and EU Law and Other Key Legal Issues in its Implementation in the Light of the Opinions of the Aarhus Convention Compliance Committee' in Marc Pallemaerts (ed) The Aarhus Convention at Ten: Interactions and Tensions Between Conventional International Law and EU Environmental Law (Europa Law Publishing 2011): $143,67$.

${ }^{31}$ Since the TFEU entered into force, Article 4(2)(e) TFEU, confirming the pre-existing situation, has made it clear that environmental policy is a competence shared between the EU and the Member States.
} 
When the Aarhus Convention was created, the right of access to documents held by Community institutions was already known in EU law. It was introduced to the EC Treaty in 1999, in Article 255 and then specified in Regulation 1049/2001. Nowadays, Article 15(1) TFEU guarantees: 'in order to promote good governance and ensure the participation of civil society, the Union's institutions, bodies, offices and agencies shall conduct their work as openly as possible'. Furthermore, Article 15(3) TFEU provides that: 'Any citizen of the Union, and any natural or legal person residing or having its registered office in a Member State, shall have a right of access to documents of the Union's institutions, bodies, offices and agencies, whatever their medium, subject to the principles and the conditions to be defined in accordance with this paragraph. General principles and limits on grounds of public or private interest governing this right of access to documents shall be determined by the European Parliament and the Council, by means of regulations, acting in accordance with the ordinary legislative procedure. Each institution, body, office or agency shall ensure that its proceedings are transparent and shall elaborate in its own Rules of Procedure specific provisions regarding access to its documents, in accordance with the regulations (....) The Court of Justice of the European Union, the European Central Bank and the European Investment Bank shall be subject to this paragraph only when exercising their administrative tasks...'. The Charter of Fundamental Rights of the European Union in Article 11(1) provides that: 'Everyone has the right to freedom of expression. This right shall include freedom to hold opinions and to receive and impart information and ideas without interference by public authorities and regardless of frontiers.' In line with the right of access to documents under Article 42 of the Charter - 'any citizen of the Union, and any natural or legal person residing or having its registered office in a Member State, has a right of access to documents of the institutions, bodies, offices and agencies of the Union, whatever their medium'.

The Public Access Regulation, mentioned above, governs the access of the public to the documents of the European Parliament, the Council, and the Commission. The Regulation aims to enable 'citizens to participate more closely in the decision-making process and guarantees that the administration enjoys greater legitimacy and is more effective and more accountable to the citizen in a democratic system'. The 'purpose is - to give the fullest possible effect to the right of public access to documents' and 'in principle, all documents of the institutions should be accessible to the public. However, certain public and private interests should be protected by way of exceptions. The institutions should be entitled to protect their internal consultations and deliberations where necessary to safeguard their ability to carry out their tasks. In assessing the exceptions, the institutions should take account of the principles in Community legislation concerning the protection of personal data, in all areas of Union activities' ${ }^{32}$ Article 2(3) of the Regulation provides that it applies to all documents held by an institution, that is to say, documents

\footnotetext{
${ }^{32}$ Public Access Regulation, preamble, para 2, 4, 11.
} 
drawn up or received by it and in its possession. Finally, Regulation 1049/2001 applies at Union level only (!) as adapted by Articles 3 to 8 of Regulation 1367/2006 of the European Parliament and the Council on the application of the Aarhus Convention to Union institutions and bodies - this contradistinction was crucial for deciding the case commented in the second part of this article.

The upmost importance of Aarhus Convention have been commented on extensively. Specialists have noted that in some respects the Convention guarantees greater protection than domestic and EU law, especially because of its relatively strong compliance mechanism. The Aarhus Convention forms an essential part of the EU environmental law. Case law of the CJEU ammounts to about 45 judgments - preliminary rulings and decisions in infringement cases, and still is growing. ${ }^{33}$

\section{ACCESS TO INFORMATION RELATING TO EMISSIONS INTO THE ENVIRONMENT - CASE C-673/13 P OF 23 NOVEMBER 2016 - EUROPEAN COMMISSION V STICHTING GREENPEACE NEDERLAND}

\section{Facts}

On 20 December 2010, Greenpeace and PAN Europe applied, on the basis of the Public Access Regulation and the Aarhus Regulation, for access to several documents relating to the initial authorisation for the placing of glyphosate on the market, granted under Directive 91/414 ${ }^{34}$. The Commission, by letter of 6 May 2011 after seeking the German authorities' prior agreement, in line with Public Access Regulation, granted access to the draft report, with the exception of its volume 4 (the document at issue), which those authorities refused to disclose. In that respect, the Commission explained that consultation with the German authorities was still ongoing and that a decision would be taken at a later time. Finally, the Commission refused access to this document, relying on the Member State's refusal. Defending its decision, the Commission stated that Germany objected to disclosure of that document on the basis of the first indent of Article 4(2) of Public Access Regulation, because of the confidential information linked to the intellectual property rights of the companies which had sought the inclusion of glyphosate in Annex I to Directive 91/414. Thereby, the detailed chemical composition of the active substance produced, details of this substance's manufacturing process, impurities information, the finished product's composition and data on the contractual relations between the companies involved had been covered up under the disputable Commission decision.

On balance, the Commission considered that the need to protect the intellectual property rights of those companies outweighed the public interest in the disclosure of the information. The Commission stated that such

\footnotetext{
33 J Jendrośka, 'Public Participation in Environmental Decision-Making Interactions Between the Convention and EU Law and Other Key Legal Issues in its Implementation in the Light of the Opinions of the Aarhus Convention Compliance Committee' (32) 93; J Jendrośka, 'Public Information and Participation in ECEnvironmental Law; Origins, Milestones and Trends' (14) 63; Schram (n 21) 79.

${ }^{34}$ Council Directive 91/414/EEC of 15 July 1991 concerning the placing of plant protection products on the market [1991] OJ L 230/1.
} 
disclosure would allow competing undertakings to copy the production processes of the companies seeking for the inclusion of glyphosate. This would lead to their considerable losses and leave their commercial interests and intellectual property rights unprotected. On the other hand, the public interest in disclosure of the information had already been taken into account, since the possible effects of glyphosate emissions were shown in other parts of the draft report that had already been made public. As regards the information relating to non-relevant impurities that was included in the document at issue, the Commission considered that it related to elements which do not present risks to health or the environment but which make it possible to reconstitute the manufacturing process of each product. Furthermore, according the Commission, it was apparent from the procedure by which glyphosate had been included in Annex I to Directive 91/414 that the requirements laid down by the Aarhus Regulation concerning public disclosure of information on the environmental effects of that substance had been taken into account. In those circumstances, protection of the interests of the manufacturers of that substance had to prevail. Therefore, the conclusion was that there was no evidence of an overriding public interest in disclosure. ${ }^{35}$

By application lodged at the Registry of the General Court on 14 October 2011, Greenpeace and PAN Europe brought an action for annulment of the above mentioned Commission decision of 10 August 2011. The General Court on the 8 October 2013 partially annulled the Commission decision refusing access to volume 4 of the Draft Assessment Report issued by the Federal Republic of Germany ${ }^{36}$. Subsequently, the European Commission brought an appeal on 17 December 2013. Finally the Court, on the 23 of November 2016, decided to: set aside the judgment of the General Court of 8 October 2013 and refered the case T 545/11 back to the General Court for a new assessment of whether the documents fall within the scope of 'information which relates to emissions into the environment'.

\section{Key legal problems of the case}

To begin with key issues of the transparency principle in EU law, an exhaustive interpretation of relevant Treaty provisions was done by Advocate General Michal Bobek in the case Commission v Patrick Breyer ${ }^{37}$. Even though there is no need to state the interest, neither Article 15 TFEU nor Charter Articles: 11 and 42 make things easier when it comes to application of the Aarhus Regulation in contradiction with the Public Access Regulation; that is to say to be granted access to environmental information if this would be contrary to general access to information rules.

The Aarhus Regulation implements the Aarhus Convention in respect of the EU institutions. For that purpose Article 6(1) of the Aarhus Regulation modifies the exceptions laid down in the Public Access Regulation to the right

\footnotetext{
${ }^{35}$ Case C-673/13 P Commission v Stichting Greenpeace Nederland and PAN Europe, paras 16-24.

${ }^{36}$ Case T 545/11 Stichting Greenpeace Nederland and PAN Europe v Commission.

${ }^{37}$ Case C-213/15 P, Opinion of Advocate General Bobek, delivered on 21 December 2016 (1), paras 4-7.
} 
of access to documents with regard to information relating to emissions into the environment: "As regards Article 4(2), first and third indents, of Regulation (EC) No 1049/2001, with the exception of investigations, in particular those concerning possible infringements of Community law, an overriding public interest in disclosure shall be deemed to exist where the information requested relates to emissions into the environment. As regards the other exceptions set out in Article 4 of Regulation (EC) No 1049/2001, the grounds for refusal shall be interpreted in a restrictive way, taking into account the public interest served by disclosure and whether the information requested relates to emissions into the environment.' 38

The case at hand incites a brief presentation and assessment of a few legal issues. The analysis of the pleas in law lodged by Greenpeace and PAN Europe on the 14 October 2011 leads to the conclusion that the crucial one was an exception provided for by Article 4(2) of the Public Access Regulation $^{39}$. The interpretation of the refusal of access clause ${ }^{40}$ in the light of the public interest protection clause has made a significant contribution to the General Court decision of 8 October $2013^{41}$ that upheld the second plea in law and annulled the Commission's decision. The second issue supporting the consecutive Commission's appeal - relies on a single ground of appeal, alleging that the General Court erred in its interpretation of the term 'information [which] relates to emissions into the environment' within the meaning of the first sentence of Article 6(1) of Aarhus Regulation. ${ }^{42}$

On one side, the Commission supported by the German Government and no less than seven European and American pesticide lobbies (!), interpreted the refusal of access clause, stating that Article 4(2) of Regulation No $1049 / 2001$ could perfectly be aplied on the ground that the undisclosed document contained confidential information relating to the intellectual property rights of the companies involved. Accepting the opinion of the German authorities, that there was no overriding public interest, as provided for in Article 4(2) of Public Access Regulation justifying disclosure of the document at issue, the Commission examined whether such public interest could be invoked in the light of the Aarhus Regulation. Considering application of Article 6(1) of that regulation, under which an overriding public interest in disclosure was supposed to exist where the information requested relates to emissions into the environment - this article did not apply to the document at issue, since it did not contain any such information. On the other hand, the Commission stated that the information in question concerned the glyphosate production process of the companies involved. On balance, the Commission considered the need to protect the companies' intellectual property rights as prevailing over the public interest in disclosure of the information. Such disclosure would, in the present case, allow competing

\footnotetext{
${ }^{38}$ Opinion of advocate general Kokott delivered on 7 April 2016 (1) Case C 673/13 P European Commission v Stichting Greenpeace Nederland and Pesticide Action Network Europe (PAN Europe), para 9.

${ }^{39}$ Case C-673/13, paras 25-27.

${ }^{40}$ Article 4(2) of that regulation provides as follows: 'The institutions shall refuse access to a document where disclosure would undermine the protection of: - commercial interests of a natural or legal person, including intellectual property, ... unless there is an overriding public interest in disclosure.'

${ }^{41}$ Case $\mathrm{T} 545 / 11$.

${ }^{42}$ Case C-673/13, paras 34-35.
} 
undertakings to copy the production processes which would lead to considerable losses for the companies involved and leave their commercial interests and intellectual property rights unprotected ${ }^{43}$. On the other hand, the public interest in disclosure of the information had already been taken into account, since the possible effects of glyphosate emissions were shown in other parts of the draft report that had already been made public. What is more, according to the Commission, apparently from the procedure by which glyphosate had been included in Annex I to Directive 91/414 - the requirements laid down by Aarhus Regulation concerning public disclosure of information on the environmental effects of that substance had been taken into account. In those circumstances, protection of the interests of the manufacturers of that substance had to prevail. Therefore, the Commission drew the conclusion that there was no evidence of prevailing public interest in disclosure. ${ }^{44}$

On the other side, the General Court - upholding the second plea in law of Greenpeace and PAN Europe maintained that the exception to the right of access designed to protect the commercial interests of a natural or legal person, laid down in the first indent of Article 4(2) of Public Access Regulation should have been discounted in this case. According to the Court, there was an overriding public interest in disclosure of the information requested since it related to emissions into the environment within the meaning of the first sentence of Article 6(1) of Aarhus Regulation.

Finnally, and aptly indeed, the Court faced the bone of contention - the concept of 'information ... [which] relates to emissions into the environment' in the light of Regulation No 1049/2001, read in conjunction with Article 6(1) of Regulation No 1367/2006 and Article 4(4) of the Aarhus Convention. The Commission stated that it must satisfy two cumulative conditions. Firstly, it must relate to emissions emanating from installations such as factories and power stations and secondly, it must concern actual emissions into the environment. ${ }^{45}$ The Court clarified that this concept must be interpreted in a way which does not render Article 339 TFEU and the first indent of Article 4(2) of Regulation No 1049/2001 wholly redundant, in so far as those articles protect professional secrecy and the commercial interests of a particular natural or legal person. The right of access to the documents of the institutions laid down by that regulation is, as the General Court pointed out, subject to certain limitations based on grounds of public or private interest, including the protection of the commercial interests of a particular natural or legal

\footnotetext{
${ }^{43}$ The Union is also a party to the Agreement on Trade-Related Aspects of Intellectual Property Rights ("TRIPS"); Council Decision 94/800/EC Concerning the Conclusion on Behalf of The European Community, as Regards Matters Within its competence, of the Agreements Reached in the Uruguay Round Multilateral negotiations (1986-1994) [1994] OJ L336/214; See: article 39(3) of which provides for the protection of data submitted with a view to obtaining market authorisation of pharmaceutical or agricultural chemicals products in certain circumstances. Although the scope of the latter provision is rather limited, it must still be observed.

${ }^{44}$ Case C-673/13, paras 22-24.

${ }^{45}$ Ibidem para 40.
} 
person. However, contrary to the Commission's claim, that concept may not be interpreted too narrowly. In line with the case-law of the Court of Justice, the Public Access Regulation is intended, as is apparent from recital 4 and Article 1 thereof, to give the fullest possible effect to the right of public access to documents of the institutions ${ }^{46}$. Similarly, Regulation No 1367/2006 aims in Article 1, to ensure the widest possible systematic availability and dissemination of the environmental information held by the institutions and bodies of the European Union.

The Court stressed that establishing a presumption that the disclosure of 'information ... [which] relates to emissions into the environment', with the exception of information relating to investigations, is deemed to be in the overriding public interest, compared with the interest in protecting the commercial interests of a particular natural or legal person, results in that the protection of those commercial interests may not be invoked to preclude the disclosure of that information. The first sentence of Article 6(1) of the Aarhus Regulation derogates from the rule requiring the weighing up of the interests laid down in Article 4(2) of the Public Access Regulation. Nonetheless, the first sentence of Article 6(1) thus allows actual implementation of the principle that the public should have the widest possible access to information held by the institutions and bodies of the European Union, therefore a narrow interpretation of that provision cannot be justified.

Reconsidering the possibility of restriction of the concept of 'information [which] relates to emissions into the environment' to information relating to emissions emanating from industrial installations, the Court stressed that such a restriction would be contrary to the express wording of point (d) of the first subparagraph of Article 4(4) of the Aarhus Convention ${ }^{47}$. That provision states that information on emissions which is relevant for the protection of the environment must be disclosed. Information concerning emissions emanating from sources other than industrial installations, such as those resulting from the use of plant protection products on plants or soil, are just as relevant to environmental protection as information relating to emissions of industrial origin. Further, restriction of the concept of 'emissions into the environment' within the meaning of the first sentence of Article 6(1) of Regulation No $1367 / 2006$ to emissions emanating from certain industrial installations, such as factories and power stations, would be contrary to that regulation's objective of disclosing environmental information as widely as possible ${ }^{48}$. What is more, that concept also covers information on foreseeable emissions into the environment from the plant protection product or active substance in question, under normal or realistic conditions of use of that product or substance, namely the conditions under which the authorisation to place that product or substance on the market was granted and which prevail in the area where that product or substance is intended to be used. ${ }^{49}$ Although the marketing of a product or substance is not sufficient in general for it to be concluded that that product or substance will necessarily be released into the

\footnotetext{
46 Judgments of 21 September 2010, Sweden and Others v API and Commission, C 514/07 P, C 528/07 P and C 532/07 P, EU:C:2010:541, para 69, and 17 October 2013, Council v Access Info Europe, C 280/11 P, EU:C:2013:671, para 28.

${ }^{47}$ Bayer CropScience and Stichting De Bijenstichting (C 442/14), para 72.

48 ibid, para 73.

${ }^{49}$ Case C-673/13, paras 74; C 442/14, para 78 and 79.
} 
environment and that information concerning the product or substance relates to 'emissions into the environment', the situation is different as regards a product such as a plant protection product, and the substances which that product contains, which, in the course of normal use, are intended to be released into the environment by virtue of their very function. In this case, foreseeable emissions, under normal or realistic conditions of use, from the product in question, into the environment are not hypothetical and are covered by the concept of 'emissions into the environment' within the meaning of the first sentence of Article 6(1) of the Aarhus Regulation ${ }^{50}$. That concept must be understood as including data that will allow the public to know what is actually released into the environment or what will be released into the environment under normal or realistic conditions of its use. It is also necessary to include in the concept of 'information [which] relates to emissions into the environment' information enabling the public to check whether the assessment of actual or foreseeable emissions, on the basis of which the competent authority authorised the product or substance in question, is correct, and the data relating to the effects of those emissions on the environment. At the same time, the Court stressed that concept may not encompass information linked, even directly, to environmental emissions 'information which concerns or relates to such emissions does not cover information with a direct or indirect link to emissions into the environment.' 51

To conclude, although the Court had not found any error in law in the General Court's judgment under appeal, it set aside the judgment of the General Court in case C-673/13 P and referred back the case for a second review, to decide on the first and third pleas in law.

\section{Implications of the judgement}

The case discused above addresses the fundamental issue - the right of access to environmental documents, and in particular, the scope of the concept of 'information on emissions into the environment'. Together with the case C-442/14 Bayer CropScience and Stichting De Bijenstichting of the same date it could perfectly be called a landmark ruling on access to environmental information.

The definitive conclusion, after the second review of the General Court is not yet known.However, we may expect that extensive interpretation of the notion of 'information which relates to emissions into the environment' and a narrow interpretation of the exceptions to the access to environmental information including the exceptional clauses protecting comercial interests will be maintaned having far-reaching consequences for legal practice. As a result, confidential information linked to the commercial or industrial interests, such as the detailed chemical composition of the substance, its manufacturing process, and the impurities and composition of the finished products, may have to be disclosed if such information is considered to be related to the 'emissions into the environment'. The CJEU's judgment

\footnotetext{
${ }^{50} \mathrm{C} 442 / 14$, para 78 and 79.

${ }^{51} \mathrm{C}-673 / 13$ P, para 78.
} 
clarifies that public interest in 'information which relates to emissions into the environment' is crucial and oftentimes overrides commercial interests. The conclusions reached by the CJEU in this judgment may have wideranging consequences for EU manufacturers of plant protection products and biocides. In general, this judgement may have significant and widespread implications for companies seeking to protect trade secrets and other sensitive information.

The case Commission v. Stichting Greenpeace Nederland, has been criticized for applying vague terminology - 'foreseeable emissions' versus 'hypothetical emissions', 'information which relates to emissions' and 'information with a sufficiently direct link to emissions' - they seem to be left for further judicial clarification.

\section{CONCLUSION}

Ensuring the highest possible degree of transparency firmly stays as a key aim of the Aarhus Convention, as it has plainly been shown by several recitals in its preamble. Cohesively, the Commission v. Stichting Greenpeace Nederland case confirms the current trend which the Court follows regarding access to environmental documents. Indeed, according to the CJEU, exceptions to disclosure must be applied restrictively as they derogate from the general principle of widest possible access to documents on emissions to the environment. Therefore, one of the effects of Article 6(1) of the Aarhus Regulation is to extend the "emissions rule" beyond the protection of business secrets so as to override the exceptions in Article 4(2) of Regulation $1049 / 2001$ relating to the protection of intellectual property and the protection of inspections and audits. The proceedings in Greenpeace Nederland are an excellent example of this. However, a wide interpretation of the term "information which relates to emissions into the environment" directly impairs companies' ability to protect business information. No wonder, that for numerous international, European and American pesticide lobbies this case became a matter of life or death. Against all odds, the EU consistently fulfils the obligations it signed up to in the Aarhus Convention. This seems to be an optimistic prognostic for environmental protection in Europe.

\section{References}

\section{Cases} PAN Europe

Case C-673/13 P Commission v Stichting Greenpeace Nederland and

Cases C-404/12 P and C-405/12 P Council of the European Union and European Commission v Stichting Natuur en Milieu and Pesticide Action Network Europe

Case 70/87 Fédération de l'industrie de l'huilerie de la CEE (Fediol)

$v$ Commission of the European Communities [1989] ECR-01781

Case C-69/89 Nakajima All Precision Co. Ltd $v$ Council of the European Communities [1991] ECR I-02069

Case C-240/09 Lesoochranárske zoskupenie VLK v Ministerstvo životného prostredia Slovenskej republiky 
Case T-188/12, Patrick Breyer v European Commission

Opinion of Advocate General Bobek delivered on 21 December 2016, Case C 213/15 P Commission v Patrick Breyer

Opinion of Advocate General Kokott delivered on 7 April 2016, Case C-673/13 P European Commission v Stichting Greenpeace Nederland and Pesticide Action Network Europe (PAN Europe)

Opinion of Advocate General Jääskinen delivered on 8 May 2014, Cases C-404/12 P and C-405/12 P Council of the European Union and European Commission v Stichting Natuur en Milieu and Pesticide Action Network Europe

\section{Legislation}

Charter of Fundamental Rights of the Union [2012] OJ C326/02

Communication from the Commission. Europe 2020. A strategy for smart, sustainable and inclusive growth [2010] COM(2010) 2020 final

Convention on Access to Information, Public Participation in Decision-making and Access to Justice in Environmental Matters, Aarhus, Denmark [1998] United Nations Treaty Series vol 2161, 447

Council Decision 94/800/EC Concerning the Conclusion on Behalf of The European Community, as Regards Matters Within its competence, of the Agreements Reached in the Uruguay Round Multilateral negotiations [1994] OJ L336/214

Council Directive 91/414/EEC of 15 July 1991 concerning the placing of plant protection products on the market [1991] OJ L230/1

Council of Europe Convention on Access to Official Documents, Troms $\varnothing$ (2009) Council of Europe Treaty Series 205

Decision 2005/370/EC of 17 February 2005 on the conclusion on behalf of the European Community, of the Convention on access to information, public participation in decision-making and access to justice in environmental matters [2005] OJ L124/1

Directive 2003/4/EC of the European Parliament and of the Council of 28 January 2003 on public access to environmental information and repealing Council Directive 90/313/EEC [2003] OJ L041/0026

Directive 2003/35/EC of the European Parliament and of the Council of 26 May 2003 providing for public participation in respect of the drawing up of certain plans and programmes relating to the environment and amending with regard to public participation and access to justice Council Directives 85/337/EEC and 96/61/EC [2003] OJ L 156/0017

Convention for the Protection of Human Rights and Fundamental Freedoms (1950) European Treaty Series 5

Explanations relating to the Charter of Fundamental Rights [2007] C 303/02

Recommendation Rec (2002)1 of the Committee of Ministers of the Council of Europe of 30 January 2002 to Member States on the guiding principles for sustainable spatial development of the European Continent 
Recommendation Rec (2002)12 of the Committee of Ministers of the Council of Europe of 16 October 2002 to Member States on education for democratic citizenship

Recommendation Rec (2001) 19 of the Committee of Ministers of the Council of Europe of 6 December 2001 to Member States on the participation of citizens in local public life

Regulation (EC) No 1367/2006 of the European Parliament and of the Council of 6 September 2006 on the application of the provisions of the Aarhus Convention on Access to Information, Public Participation in Decision-making and Access to Justice in Environmental Matters to Community institutions and bodies [2006] OJ L264/13

Regulation (EC) No 1049/2001 of the European Parliament and of the Council of 30 May 2001 regarding public access to European Parliament, Council and Commission documents [2001] OJ L145/43

Treaty establishing the European Community [2002] OJ C 325/33

Treaty on the Functioning of the European Union [2012] OJ C 326/01

Treaty on European Union [2012] OJ C 326/13

\section{Bibliography}

Bándi G, 'Right to environment - procedural guarantees' in Bándi Gyula (ed) Environmental democracy and law: public participation in Europe (Europa Law Publishing 2014)

Ebbesson J, Information, Participation and Access to Justice: the Model of the Aarhus Convention (Stockholm University 2002) http://www2.ohchr.org/english/issues/environment/environ/bp5.htm

European Environment Agency, The European environment - state and outlook 2015: synthesis report (Copenhagen 2015)

Fabra Aguilar A, Popovic N, 'Lawmaking in the United Nations: the UN Study on Human Rights and the Environment' (1994) 17 Review of European Community \& International Environmental Law 197

Geiger R, Khan D-E, Kotzur M (eds), European Union Treaties. A Commentary. Treaty on European Union. Treaty on the Functioning of the European Union (C.H.BECK Hart 2015)

Hallo R, 'Access to Environmental Information. The reciprocal Influences of EU Law and the Aarhus Convention' in Pallemaerts Marc (ed) The Aarhus Convention at Ten. Interactions and Tensions between Conventional International Law and EU Environmental Law (Europa Law Publishing 2011)

Jendrośka J, 'Public Participation in Environmental Decision-Making Interactions Between the Convention and EU Law and Other Key Legal Issues in its Implementation in the Light of the Opinions of the Aarhus Convention Compliance Committee' in Marc Pallemaerts (ed) The Aarhus Convention at Ten: Interactions and Tensions Between Conventional International Law and EU Environmental Law (Europa Law Publishing 2011): 143

---- 'Public Information and Participation in EC Environmental Law; Origins, Milestones and Trends' in: Macrory Richard (ed) Reflections on 30 years of EU environmental law. A High Level of Protection? (Europa Law Publishing 2006) 
-- Radecki W, Konwencja o dostepie do informacji, udziale społeczeństwa w podejmowaniu decyzji oraz dostępie do sprawiedliwości $w$ sprawach dot. Środowiska (Wrocław: Centrum Prawa Ekologicznego 1999)

Lyndon ML, 'Trade Secrets and Information Access in Environmental Law' in Rochelle C Dreyfuss \& Katherine J Strandburg (eds) The Law and Theory of trade secrecy: a handbook of contemporary research (Edward Elgar 2011)

Macrory R, (ed) Reflections on 30 years of EU environmental law. A High Level of Protection? (Europa Law Publishing 2006)

Oliver P, 'Access to Information and to Justice in EU Environmental Law: The Aarhus Convention' (2013) 36 Fordham International Law Journal 1423-1470

Pallemaerts M (ed) The Aarhus Convention at Ten. Interactions and Tensions between Conventional International Law and EU Environmental Law (Europa Law Publishing 2011)

Requests for internal review. Practical Guide. http://ec.europa.eu/environment/aarhus/requests.htm

De Sadeleer N, 'Enforcing EUCHR Principles and Fundamental Rights in Environmental Cases' (2012) 39 Nordic Journal of International Law

Schram F, 'From a General Right of Access to Environmental Information in the Aarhus Convention to a general right of Access to All Information in Official Documents. The Council of Europe's Tromsø Convention' in Pallemaerts Marc (ed) The Aarhus Convention at Ten: Interactions and Tensions Between Conventional International Law and EU Environmental Law (Europa Law Publishing 2011)

Shaw MN, International Law (Cambridge University Press 2008)

United Nations Economic Commission for Europe, Convention on Access to Information, Public Participation in Decision-making and Access to Justice in Environmental Matters (Aarhus Convention) The Aarhus Convention: An implementation guide (United Nations Publications 2014) 